\title{
PReS-FINAL-2282: Amaurosis as a presenting sign of antiphospholipid syndrome secondary to systemic lupus erythematosus - case report
}

\author{
A Omerčahić-Dizdarević ${ }^{*}$, S Mesihović-Dinarević ${ }^{2}$, V Selmanovic (Mulaosmanovic) ${ }^{1}$, A Čengić ${ }^{1}$ \\ From 20th Pediatric Rheumatology European Society (PReS) Congress \\ Ljubljana, Slovenia. 25-29 September 2013
}

\begin{abstract}
Introduction
Antiphosphospholipid syndrome (APS) secundary to systemic lupus erythematosus (SLE) can be recognised in children with arterial or venous thrombosis. Amaurosis due to thrombosis of central retinal vene is rarely presenting manifestation of SLE with secondary APS.
\end{abstract}

\section{Objectives}

To present APS secundary to SLE with aggresive ophtalmological onset in 17 years old female.

\section{Methods}

We report a patient with unilateral amaurosis due to thrombosis of central retinal vene. Amaurosis was a reason for her urgent admission at Ophtalmology. She was transferred to Pediatric rheumatology department as suspected SLE. The patient had rapidly developing disease. Eleven days after the attack of retinal vene thrombosis, she became febrile with malar rash, facial ulcer, neurological symptoms (right Mingazzini positive), arterial hypertension, haemathological abnormalities, proteinuria and immonological disorders. Head MRI-MRA was performed and suboclusion of left medial cerebral artery was found. The diagnosis of APS secundary to SLE was established.

\section{Results}

The patient significantly improved with aggresive immunosupresive and prompt anticoagulant therapy but ohtalmological complication have been improved slowly with uncertain prognosis.

${ }^{1}$ Allergology, Rheumatology and Clinical Immunology, Children's Hospital University Clinical Center, Sarajevo, Bosnia and Herzegovina

Full list of author information is available at the end of the article

\section{Conclusion}

The patients with SLE related symptoms have to be reffered to rheumatologist immediately because APS secundary to SLE may have aggressive thrombotic onset and cause serious organs damages.

\section{Disclosure of interest}

None declared.

\section{Authors' details \\ ${ }^{1}$ Allergology, Rheumatology and Clinical Immunology, Children's Hospital University Clinical Center, Sarajevo, Bosnia and Herzegovina. \\ ${ }^{2}$ Cardiology, Children's Hospital University Clinical Center, Sarajevo, Bosnia and Herzegovina.}

Published: 5 December 2013

doi:10.1186/1546-0096-11-S2-P272

Cite this article as: Omerčahić-Dizdarević et al:: PReS-FINAL-2282:

Amaurosis as a presenting sign of antiphospholipid syndrome

secondary to systemic lupus erythematosus - case report. Pediatric Rheumatology 2013 11(Suppl 2):P272.

Submit your next manuscript to BioMed Central and take full advantage of:

- Convenient online submission

- Thorough peer review

- No space constraints or color figure charges

- Immediate publication on acceptance

- Inclusion in PubMed, CAS, Scopus and Google Scholar

- Research which is freely available for redistribution 